Abstracta Iranica Abstracta Iranica

Revue bibliographique pour le domaine irano-aryen

Volume 40-41 | 2019

Comptes rendus des publications de 2017-2018

\title{
Jason Schlude, Benjamin Rubin (eds.). Arsacids, Romans and Local Elites. Cross-Cultural Interactions of the Parthian Empire
}

Vito Messina

\section{(2) OpenEdition \\ Journals}

Electronic version

URL: http://journals.openedition.org/abstractairanica/48010

DOI: $10.4000 /$ abstractairanica.48010

ISBN: 1961-960X

ISSN: 1961-960X

Publisher:

CNRS (UMR 7528 Mondes iraniens et indiens), Éditions de l'IFRI

Electronic reference

Vito Messina, "Jason Schlude, Benjamin Rubin (eds.). Arsacids, Romans and Local Elites. Cross-Cultural Interactions of the Parthian Empire", Abstracta Iranica [Online], Volume 40-41 | 2019, document 7, Online since 15 July 2019, connection on 21 April 2021. URL: http://journals.openedition.org/ abstractairanica/48010 ; DOI: https://doi.org/10.4000/abstractairanica.48010

This text was automatically generated on 21 April 2021

Tous droits réservés 


\title{
Jason Schlude, Benjamin Rubin (eds.). Arsacids, Romans and Local Elites. Cross-Cultural Interactions of the Parthian Empire
}

\author{
Vito Messina
}

\section{REFERENCES}

Jason Schlude, Benjamin Rubin (eds.). Arsacids, Romans and Local Elites. Cross-Cultural Interactions of the Parthian Empire. Oxford-Philadelphia: Oxbow, 2017, 158 p., with many $\mathrm{b} / \mathrm{w}$ figures in the text, ISBN 978-1-78570-592-2 (ISBN digital 978-1-78570-593-9)

1 Since the accession of the Achaemenids, the vast territories of the ancient Near East experienced the government of complex systems of elites and bureaucracies over multi-cultural and multi-ethnic populations. The dynasty of the Arsacids, continued a long-lasting tradition and, during their rule, long-distance trades benefited of this political organization, despite the many conflicts and wars against the growing power of Rome.

2 This volume brings together the researches of several scholars on the subject of the Arsacid dynasty of Parthia and its interactions with neighboring states. It is divided into chapters, signed by different Authors, which were originally delivered as lectures at the annual meeting of the American Schools of Oriental Research in 2012, 2013, and 2014: these papers contribute to the discussion of Parthian intercultural communications and are interested in the interactions of the Arsacids with their neighbors, especially Rome. These interactions are explored with an intentionally broad and flexible definition of intercultural communication, including treatment of several manners of exchange, such as war, diplomacy, art. The role played by local elites in the negotiation with interfaced political entities, but basically Rome, is also 
investigated, in order to underscore the complexity and variety of what we can define long-lasting processes.

3 The aim of these miscellanea is to put forward the scholarship on Parthian history and archaeology by investigating the intercultural communication of their empire, and enlightening phenomena like the adaptation of Achaemenid, Greek and other traditions, and engagement in war, but also diplomacy, so as to benefit of productive periods of peace. In this perspective, it is particularly interesting that, besides the confrontation of superpowers, focus is also given to local states taking the opportunity to use Roman and Parthian political, military and cultural resources in their own bid of power.

\section{AUTHORS}

\section{VITO MESSINA}

Università di Torino 